\title{
PENGEMBANGAN MEDIA KOMIK DALAM PEMBELAJARAN MODEL ROUND TABLE UNTUK MENINGKATKAN KEMAMPUAN MENULIS CERITA SISWA KELAS IV SD
}

\author{
Efi Ika Febriandari ${ }^{1}$, Bambang Yulianto ${ }^{2}$, Wahyu Sukartiningsih ${ }^{3}$ \\ Pendidikan Dasar, Pascasasrjana Universitas Negeri Surabaya \\ email:efi.ika.f@gmail.com
}

\begin{abstract}
Abstrak
Penelitian ini dilaksanakan atas dasar rendahnya kemampuan siswa dalam menulis cerita. Ada lima alasan : (1) kurang mendapat contoh yang konkret, (2) rendahnya minat baca, (3) kesulitan memahami isi cerita, (4) kesulitan menuangkan ide, (5) dalam penulisan tidak runtut. Untuk mengatasi permasalahan tersebut dikembangkan media komik. Secara umum penelitian ini bertujuan untuk menjelaskan proses dan kualitas media komik dalam pembelajaran model round table untuk meningkatkan kemampuan menuli cerita kelas IV SD. pemecahan masalah sosial siswa berdasarkan pengalaman dan pengetahuan yang dimilikinya. Penelitian ini merupakan penelitian pengembangan dengan menggunakan metode kualitatif dan kualitatif. Hasil penelitian diperoleh hasil presentase kelayakan isi/materi, kebahasaan, dan gambar secara berturut -turut sebesar 96,9\%, $97,2 \%$, dan $89,3 \%$. Semua kategori tersebut termasuk kategori berkualitas (sangat baik) perolehan hasil observasi terhadap aktivitas guru dan siswa berturut-turut adalah 98,4 \% dan 97,1\%. Rata-rata hasil belajar siswa sebesar 79,8, nilai sesuai dengan kriteria ketuntasan yaitu $\geq 67$.Respon guru dan siswa terhadap media komik adalah 96,9 \% dan 97,2 \%. Berdasarkan hasil penelitian menunjukan bahwa media komik dalam pembelajaran model round table yang dikembangkan baik digunakan.
\end{abstract}

Kata Kunci: Pengembangan media komik, round table, menulis cerita

\begin{abstract}
The research was conducted on the basis of low ability students in writing the story. There are five reasons: (1) lack of concrete examples, (2) lack of interest in reading, (3) difficulty understand the story, (4) the difficulties ideas, (5) the writing is not coherent. To overcome these problems developed the comic medium. In general, this study aims to explain the process and the quality of the comics media round table in learning models to improve the ability to write stories fourth grade. solving social problems of students based on its experience and knowledge. This research is the development by using qualitative and qualitative methods. Research results eligibility percentage content / material, linguistic, and images respectively -turut by 96.9\%, 97.2\%, and 89.3\%. All of those categories including quality category (very good) gain on the observation of the activities of teachers and students respectively were $98.4 \%$ and $97.1 \%$. The average student learning outcomes at 79.8, the value in accordance with the criteria of completeness that $\geq 67$.Respon teachers and students of the comics medium is $96.9 \%$ and $97.2 \%$. Based on the results of the study showed that the medium of comics in the learning model of a round table that developed well used.
\end{abstract}

Keyword: medium development comics, round table, writing stories

\section{PENDAHULUAN}

Kegiatan belajar mengajar dipengaruhi oleh beberapa faktor, diantaranya adalah media pembelajaran dan model pembelajaran. Menurut Slameto, (1995:35) pemilihan media yang tepat, dapat membantu siswa untuk membentuk pengertian di dalam jiwanya sehingga siswa dapat mengaplikasikannya dalam kehidupan sehari-hari. Salah satu media pembelajaran yang efektif adalah media pembelajaran komik, melalui penggambaran dalam bentuk lukisan atau karikatur tentang orang, gagasan atau situasi yang didesain untuk menyampaikan pesan dari pembuat dalam pembelajaran, terutama dalam menjelaskan rangkaian isi bahan dalam satu urutan logis atau mengandung makna (Sudjana dan Rivai, 2005:58).

Selain penggunaan media, dipengaruhi juga model pembelajaran. Salah satu model pembelajaran yang efektif adalah model pembelajaran kooperatif tipe round table. Menurut Lie (2010:62), "Pembelajaran kooperatif melalui strategi round table dapat digunakan dalam semua mata pelajaran dan untuk semua tingkatan usia anak didik. "Round table" merupakan teknik menulis yang menerapkan pembelajaran tentang menunjuk tiap-tiap anggota kelompok untuk berpartisipasi secara bergiliran dalam kelompoknya dengan membentuk meja bundar atau duduk melingkar (Mccaffety, 2006:191)". 
Faktor lain yang mempengaruhi keberhasilan belajar siswa selain pemilihan model pembelajaran adalah faktor internal yaitu dari dalam diri siswa sendiri yakni kemampuan aktualisasi diri siswa. Menurut Hamalik (2010:177), aktualisasi diri yaitu dorongan untuk tumbuh, untuk menjadi dan untuk belajar. Pada pembelajaran round table siswa merasa nyaman dalam proses pembelajaran karena mereka sangat menyukai tantangan dalam belajar.

Pendidikan di Indonesia menempatkan bahasa Indonesia sebagai salah satu bidang studi yang diajarkan di sekolah. Menurut Tarigan (2008) keterampilan berbahasa mempunyai empat komponen yaitu: (1) keterampilan menyimak; (2) keterampilan berbicara; (3) keterampilan membaca; dan (4) keterampilan menulis, dan keempat keterampilan tersebut saling berhubungan satu sama lain.

Rendahnya kemampuan menulis cerita siswa disebabkan 1) kurangnya media yang disediakan, 2) siswa hanya menerima pembelajaran menulis dari ceramah guru tanpa adanya media visual yang membantu siswa untuk belajar menulis dan memahami cerita, 3) pada proses pembelajaran guru tidak menggunakan model pembelajaran yang inovatif dan sesuai dengan kebutuhan siswa pada materi menulis cerita, sehingga guru perlu berupaya dalam mengembangkan media dan menggunakan model pembelajaran yang inovatif dengan maksud agar tujuan pembelajaran dapat tercapai khususnya dalam pembelajaran menulis cerita.

Berdasarkan latar belakang masalah yang telah diuraikan sebelumnya, dapat disusun rumusan masalah yang akan dipecahkan dalam penelitian ini. Rumusan masalah tersebut, yaitu sebagai berikut: 1) bagaimanakah proses pengembangan media komik dalam pembelajaran model round table untuk meningkatkan kemampuan menulis cerita siswa kelas IV SD?, 2) bagaimana kualitas media komik dalam pembelajaran model round table untuk meningkatkan kemampuan menulis cerita siswa kelas IV SD yang dikembangkan berdasarkan kelayakan materi, bahasa dan kegrafikaan? 3) bagaimana kualitas media komik dalam pembelajaran model round table untuk meningkatkan kemampuan menulis cerita siswa kelas IV SD yang dikembangkan dilihat dari penggunaannya di kelas? Rumusan ini diperinci menjadi dua submasalah yaitu dilihati dari sudut pandang guru dan sudut pandang siswa.

Adapun tujuan penelitian ini adalah mendeskripsikan proses pengembangan media komik dalam pembelajaran model round table untuk meningkatkan kemampuan menulis cerita siswa kelas IV SD dan mendeskripsikan kualitas media komik dalam pembelajaran model round table untuk meningkatkan kemampuan menulis cerita siswa kelas IV SD yang dikembangkan. Manfaat penelitian ini diharapkan mampu memberikan sumbangan dalam kegiatan pembelajaran bahasa dan sastra Indonesia, referensi bagi perpustakaan, dan informasi baru tentang materi sastra dalam konteks pembuatan media komik materi menulis cerita, khususnya untuk melengkapi perangkat pembelajaran bagi siswa serta merupakan masukan bagi guru.

Hasil penelitian ini adalah media komik dalam pembelajaran round table materi menuli cerita. Media komik ini disusun berdasarkan kurikulum 2013 dengan rincian isi media terdiri atas halaman judul, daftar isi, materi bahan ajar, dan kuis, sedangkan bentuk fisik media cetak dengan berukuran salah satu standar iso A4 dengan berat 100 gram mempunyai panjang dan lebar standard $(210 \times 297 \mathrm{~mm})$; b) memuat \pm 50 halaman, yang terdiri dari sampul muka, isi, dan sampul belakang; c) spasi 1,5 dengan jenis huruf pada judul media font Arial dengan ukuran 36pt (point), teks komik Comic Sans MS size 36pt, times new roman 12pt pada kuis; d) menggunakan kertas foto glossy untuk sampul, baik sampul muka dan sampul belakang serta isi media yang dicetak dengan tinta berwarna; e) jenis gambar pada komik yaitu gambar kartun; f) menggunakan bahasa yang dialogis dan komunikatif.

\section{METODE}

Ditinjau dari aspek tujuan, penelitian ini merupakan penelitian pengembangan. Penelitian pengembangan merupakan strategi atau metode yang ampuh untuk memperbaiki praktik. Penelitian ini merupakan suatu proses atau langkah-langkah untuk mengembangkan produk baru atau untuk menyempurnakan produk-produk yang telah ada yang dapat dipertanggungjawabkan (Sukmadinata, 2005:164). Pendekatan yang digunakan yaitu kombinasi kualitatif-kuantitatif model sequential exploratory. Model sequential exploratory adalah metode penelitian kombinasi yang menggabungkan metode penelitian kualitatif dan kuantitatif (Sugiyono, 2013:415). Desain penelitian ini mengacu Four-D Model. Model pengembangan ini terdiri atas empat tahap pengembangan yaitu pendefinisian (define), perancangan (design), pengembangan (develop) dan penyebaran (disseminate) (Thiagarajan dalam Trianto, 2007:65). 
Dalam penelitian ini pengembangan media komik dalam pembelajaran model round table materi menulis cerita diadaptasi hanya sampai pada tahap pengembangan, sehingga media komik dalam pembelajaran model round table telah dikembangkan hanya digunakan pada sekolah uji coba, tanpa disebarkan pada sekolah lain.

Tahap pendefinisian bertujuan untuk menetapkan dan mendefinisikan syarat-syarat pembuatan buku suplemen. Ada lima langkah pokok dalam tahap pendefinisian. Tahap tersebut yaitu analisis awal akhir, analisis siswa, analisis konsep, analisis tugas, dan analisis tujuan pembelajaran. Pada tahap perancangan, media ini disusun dan ditulis sesuai dengan syarat dari BSNP 2007 yaitu memperhatikan kelayakan isi, kelayakan bahasa, dan kelayakan kegrafikaan. Media komik yang telah ditulis dan disusun merupakan draf I, langkah selanjutnya draf I diberikan pada tim validator untuk diuji kelayakannya. Penilaian, masukan, dan saran dari validator digunakan untuk merevisi draf I. Berdasarkan masukan dari validator draf I direvisi, hasil revisi ini disebut dengan draf II. Draf II diberikan kembali pada tim validator untuk diberikan penilaian, hasil revisi pada draf II disebut dengan draf III. Kegiatan dilanjutkan dengan uji terbatas draf III dan uji coba luas.

Data dalam penelitian ini antara lain:1) data proses pengembangan merupakan data dari hasil tahap pendefinisian dan tahap perancangan. Data hasil tahap pendefinisian yaitu berupa rumusan KI dan KD. Data hasil tahap perancangan berupa penilaian dari tim validator untuk draf I media komik dalam pembelajaran model round table. Data hasil tahap pengembangan berupa penilaian dari tim validator untuk draf II dan data penilaian media dari sudut pandang guru dan siswa, 2) data kualitas media dalam pembelajaran model round table dari hasil tahap pengembangan yaitu skor nilai dari validator dan calon pengguna yang dirinci sebagai berikut, a) skor nilai hasil validasi draf II media komik dalam pembelajaran model round table untuk kelayakan materi, bahasa dan kegrafikaan digunakan sebagai data untuk menjawab masalah kualitas media komik dalam pembelajaran model round table dari segi produk, b) skor nilai dari data analisis guru, analisis siswa dan hasil belajar siswa baik dari uji coba terbatas maupun uji coba luas sebagai data untuk kualitas media komik dalam pembelajaran model round table dari segi penggunaan.

Sumber data pada penelitian ini yaitu, (1) sumber data dari proses pengembangan (develop) yaitu standar isi pada Kurikulum 2013 (2) sumber data dari penilaian kualitas buku suplemen materi sastra terdiri dari 54 responden dengan rincian yaitu, validator aspek materi dan validator bahasa terdiri dari 1 orang, validator aspek kegrafikaan terdiri atas 1 orang, calon pengguna media komik dalam pembelajaran model round table yang terdiri dari 52 orang, yaitu 1 guru dan 25 siswa kelas IVA SDN Simokerto VI/140 Surabaya yang dijadikan responden dalam uji coba terbatas, dan penggunan media komik yang terdiri atas 25 siswa dan 1 guru kelas IV SDN Simokerto VI/140 Surabaya yang dijadikan responden dalam uji coba luas.

Teknik pengumpulan data yang digunakan dalam penelitian ini adalah dokumentasi, validasi, observasi, angket dan tes hasil belajar siswa. Instrumen penelitian yang akan digunakan dalam penelitian ini adalah lembar pemetaan KI, KD dan indikator-indikator; lembar pemerolehan bahan ajar; lembar validasi media komik dalam pembelajaran round table; lembar validasi media komik untuk penyajian; lembar validasi media komik untuk kebahasaan,; lembar validasi media komik untuk kegrafikan; lembar observasi terhadap aktivitas guru selama penggunaan draf media komik; lembar angket terhadap respons penggunaan media oleh guru; lembar observasi terhadap aktivitas siswa selama penggunaan draf media komik; lembar hasil belajar siswa terhadap pencapaian tujuan pembelajaran; dan lembar angket terhadap respons penggunaan media oleh siswa.

\section{HASIL DAN PEMBAHASAN}

Proses pengembangan media komik, penelitian ini menggunakan model 4D yang diadopsi dari Thiagarajan yang meliputi empat tahap, yaitu pendefinisian (define), perancangan (design), pengembangan (develop), dan penyebaran (dessimate). Namun penelitian ini berakhir pada tahap pengembangan karena mengingat keterbatasan waktu dan biaya, sehingga media komik yang dikembangkan hanya digunakan pada sekolah yang digunakan sebagai tempat penelitian tanpa disebarkan pada sekolah lain. Ketiga tahapan yang dilakukan merupakan satu rangkaian utuh yang dilaksanakan beruntutan. Hasil penelitian yang diperoleh dalam proses pengembangan media komik ini adalah tahap pendefinisian, perancangan dan pengembangan.

Pada tahap perancangan bertujuan untuk mendapatkan draf awal media komik yang dikembangkan. Hasil tahap design ini adalah rancangan awal berupa media komik draf 1 . Tahap ini meliputi penyusunan naskah dan desain awal 
media komik. Penulisan dan penyusunan draf 1 kegiatan utama yang dilakukan adalah pengumpulan bahan dan perumusan ide yang berkaitan dengan materi sastra yang tercantum pada KI dan KD. Selain itu, dilakukan pula kajian berbagai model pembelajaran untuk menentukan model pembelajaran yang tepat sesuai dengan materi dan media komik yang dikembangkan yaitu model pembelajaran model round table sehingga menghasilkan media komik dalam pembelajaran model round table untuk meningkatkan kemampuan menulis cerita kelas IV SD.

Validator yang memvalidasi kelayakan materi dan bahasa merupakan ahli pada bidang pembelajaran bahasa dan sastra Indonesia. Sementara itu, validator yang memvalidasi kegrafikaan yaitu ahli pada bidang kegrafikaan/desain grafis. Hasil validasi komponen kelayakan materi memperoleh skor 26 dengan persentase $81,2 \%$ dan dikatakan sangat baik digunakan dengan sedikit revisi. Komponen kelayakan bahasa memperoleh skor 28 dengan persentase $77,8 \%$ dan dikatakan baik digunakan dengan sedikit revisi. Komponen kelayakan kegrafikan memperoleh skor 21 dengan persentase 75\% dan dikatakan baik digunakan dengan sedikit revisi.

Tahap pengembangan adalah kelanjutan dari tahap perancangan yang menghasilkan media komik dalam pembelajaran model round table. Pada tahap ini yang dilakukan peneliti adalah merevisi hasil dari setiap validator. Hasil dari revisi I draf I, kemudian diajukan kepada tim validator. Pada tahap ini, beberapa hal yang dapat dilakukan dapat diuraikan sebagai berikut. (a) revisi hasil validasi draf I, (b) validasi media komik draf II, (c) revisi hasil validasi draf II , (d) uji coba terbatas, (d) uji coba luas.

Kualitas media komik dalam pembelajaran model round table dinilai berdasarkan produk dan penggunaanya di kelas. Penilaian media komik dalam pembelajaran model round table berdasarkan produk divalidasi oleh beberapa validator yang ahli di bidang materi, bahasa, dan gambar. Sementara itu, kualitas media komik dalam pembelajaran round table dari segi penggunaan di kelas dinilai berdasarkan aktivitas guru, respons guru, aktivitas siswa, respons siswa, dan hasil belajar siswa.

Kualitas media komik dari segi produk diperoleh dari beberapa saran dan masukan yang diberikan oleh beberapa validator maka media komik ini perlu dilakukan revisi I draf I, hasil revisi I menjadi draf II. Sebelum peneliti melakukan uji coba terbatas, draf II media komik divalidasi kembali pada tim validator untuk dinilai kembali kelayakannya. Hasil rekapitulasi penilaian dari tim validator terhadap draf II media komik adalah berdasarkan kelayakan materi memperoleh skor 31 dengan persentase $96,9 \%$ dengan kriteria sangat baik, kelayakan bahasa memperoleh skor 35 dengan pesentase $97,2 \%$ dengan kriteria sangat baik, kelayakan gambar memperoleh skor rata-rata 25 dengan persentase $89,3 \%$ dengan kriteria sangat baik. Hasil dari validasi draf II direvisi kembali sesuai masukan dan saran dari tim validator. Penyuntingan draf II media komik menjadi draf III media komik dilakukan sampai mendapat persetujuan dari tim validator. Setelah mendapat persetujuan dan direvisi, maka media komik draf III siap untuk diujicobakan secara terbatas.

Kuliatas media komik dari segi penggunaannya dapat dilihat dari hasil analisis responsden pengguna media komik yaitu guru dan siswa. Uji kelayakan media komik dilakukan pada uji coba terbatas dan uji coba luas. Berikut rincian kualitas kelayakan media komik dari sudut pandang guru dan siswa. Kelayakan media komik dari sudut pandang guru dilihat dari hasil aktivitas guru, dan respons guru terhadap media komik . Hasil pengamatan aktivitas guru dan aktivitas siswa diamati oleh dua pengamat yaitu guru kelas IVB dan teman sejawat. Pengamat mengamati seluruh aktivitas guru baik pada uji coba terbatas maupun uji coba luas. Rata-rata persentase pada uji coba terbatas adalah $91,3 \%$ dan meningkat menjadi $98,4 \%$ pada saat uji coba luas. Dengan demikian dapat disimpulkan bahwa aktivtas guru pada pembelajaran sastra dengan sangat aktif karena batas persentase yang diperoleh untuk aktivitas guru dengan kriteria sangat baik adalah 80\%-100\%. Dalam penlitian ini angket respons guru diberikan pada uji coba terbatas diberikan kepada teman sejawat dan pada saat uji coba luas angket respons guru diberikan kepada guru kelas IVB SDN Simokerto VI/140 Surabaya. Analisis respons guru terhadap penggunaan media komik diketahui bahwa memeroleh hasil 90,6\% dengan kriteria sangat layak.

Kelayakan media komik dari sudut pandang siswa dilihat dari hasil aktivitas siswa, dan respons siswa, dan hasil belajar siswa selama penggunaan buku suplemen materi sastra. Aktivitas siswa dirancang berdasarkan aktvitas guru dengan sintaks pada model pembelajaran round table saat menggunakan media komik. Aktivitas siswa mulai dari kegiatan awal, inti, dan kegiatan akhir diamati oleh dua pengamat baik pada saat uji coba terbatas maupun uji coba luas. Hasil dari pengamatn tersebut 
kemudian dirata-rata dan disajikan dalam bentuk persentase diketahui bahwa pada uji coba terbatas skor yang diperoleh pengamat 1 jumlah skor total 60 dengan persentase $88,2 \%$ dan pengamat 2 jumlah skor yang diperoleh 62 dengan perentase $91,2 \%$. Hasil pengamatan tersebut dijadikan refleksi agar pembelajaran sastra pada uji coba luas aktivitas siwa lebih aktif lagi. Pada uji coba luas jumlah skor yang diperoleh pengamat 1 adalah 65 dengan persentase $95,6 \%$, sedangakan jumlah skor pada pengamat 2 adalah 67 dengan persentase $98,5 \%$. Rata-rata persentase pada uji coba terbatas adalah $89,7 \%$ dan meningkat menjadi $97,1 \%$ pada uji coba luas. Dengan demikian dapat disimpulkan bahwa aktivitas siswa pada pembelajaran menulis cerita dengan sangat baik karena batas persentase yang diperoleh untuk aktivitas siswa dengan kriteria sangat baik.

Analisis respon siswa diketahui bahwa persentase respons siswa terhadap penggunaan media komik pada uji coba terbatas $95.8 \%$ dan termasuk dalam kategori sangat layak Sementara itu, hasil respons siwa pada uji coba luas mendapatkan persentase total $97,2 \%$ termasuk kategori sangat layak. Oleh sebab itu, media komik dalam pembelajaran model round table yang dikembangkan termasuk dalam kategori sangat layak, sebab media komik dalam pembelajaran model round table dikatakan sangat layak apabila memperoleh persentase $80 \%-100 \%$. Dengan demikian, media komik dalam pembelajaran model round table yang dihasilkan dapat dikatakan berkualitas sehingga dapat digunakan dalam penelitian untuk siswa kelas IV SDN Simokerto VI/140 Surabaya.

Untuk mengetahui tingkat keberhasilan siswa dalam pembelajaran materi menulis cerita dengan menggunakan media komik, akan disajikan tebel yang menunjukkan pemerolehan nilai siswa sebelum menggunakan media komik dan setelah menggunakan media komik. Nilai KKM pada mata pelajaran Bahasa Indonesia kelas IV adalah $\geq 70$. Hasil belajar berupa ketuntasan individu dan ketuntasan klasikal pada uji coba terbatas dan uji coba luas. Secara klasikal, tingkat keberhasilan siswa sebelum menggunakan media komik dapat dihitung dengan cara jumlah siswa yang tuntas belajar memperoleh hasil $40 \%$, sedangkan untuk siswa yang tidak tuntas belajar mendapatkan hasil $60 \%$ dan rata-rata kelas memperoleh hasil 64.2. Setelah menggunakan media komik ada peningkatan yang signifikan pada nilai pre test dan post test. Secara klasikal, tingkat keberhasilan siswa setelah menggunakan media komik dapat dihitung dengan cara jumlah siswa yang tuntas belajar memperoleh hasil $92 \%$, sedangkan siswa yang tidak tuntas belajar mendapatkan hasil $8 \%$ dan rata-rata nilai 25 siswa yaitu 79.9. Hasil belajar siswa dari hasil pretest dan post-test mengalami peningkatan sebesar $14,44 \%$.

Setelah melakukan uji coba terbatas peneliti menganalisis data hasil uji coba lalu merevisi media komik draf II menjadi draf III. Setelah itu, draf III di ujicoba luaskan pada siswa kelas IVB SDN Simokerto VI/140 Surabaya dengan jumlah responsden yaitu 26 dengan rincian 25 siswa dan 1 guru. Hasil belajar siswa Secara klasikal, tingkat keberhasilan siswa sebelum menggunakan media komik materi menulis cerita memperoleh hasil $57 \%$, sedangkan untuk siswa yang tidak tuntas belajar memperoleh hasil 43\% dan rata-rata kelas memperoleh hasil 71.2 Dengan banyaknya siswa yang tidak tuntas pada saat pre test, maka kegiatan post test peneliti menggunakan media komik materi menulis cerita. Setelah menggunakan media komik ada peningkatan yang signifikan pada nilai pre test dan post test. Secara klasikal, tingkat keberhasilan siswa setelah menggunakan media komik siswa yang tuntas belajar memperoleh hasil $86 \%$, sedanggkan siswa yang tidak tuntas belajar memperoleh hasil $14 \%$ dan rata-rata nilai 25 siswa yaitu 82.5. Hasil belajar siswa dari hasil pre-test dan post-test mengalami peningkatan sebesar 11.30. Dari hasil ketuntasan klasikal pre-test dan post-test mengalami peningkatan sebesar 29\%. Berdasarkan nilai standar ketuntasan minimal yang diterapkan, maka hasil post-test dinyatakan tuntas

\section{DISKUSI HASIL PENELITIAN}

Dari hasil penelitian yang telah dianalisis dapat dinyatakan bahwa media pembelajaran komik yang dikembangkan oleh peneliti mampu meningkatkan kemampuan menulis yang dimiliki oleh siswa. Berdasarkan hasil pengamatan pada uji coba terbatas dan uji coba luas siswa sangat antusias dalam mengikuti kegiatan pembelajaran, berbeda dengan kegiatan pembelajaran sebelum menggunakan media komik. Hal ini sesuai dengan pernyataan (Trimo, 1997:21) sebagai salah satu media visual, komik tentu memiliki kelebihan tersendiri jika dimanfaatkan dalam kegiatan belajar mengajar. Kelebihan komik dalam kegiatan belajar mengajar antara lain menambah pembendaharaan kata- kata pembacanya, mempermudah anak didik menangkap hal- hal atau rumusan yang abstrak, dapat mengembangkan minat baca anak dan salah satu bidang studi. 
Hasil dari pre test tidak memenuhi target, berdasarkan Kriteria Ketuntasan Minimal (KKM) batas minimal pelajaran Bahasa Indonesia adalah $\leq$ 70. Dari 25 siswa yang mengikuti pelajaran Bahasa Indonesia materi menulis, ada 12 siswa yang tidak memenuhi kriteria ketuntasan minimum dan sebanyak 13 siswa mampu melampaui KKM yang telah ditentukan. Skor terendah dalam kegiatan pre test adalah 60, didapatkan oleh Aryo Ramadani. Sedangkan skor tertinggi didapatkan oleh Ine Grace Dewanti dengan perolehan 85 , dan hanya satu siswa yang mendapatkan nilai tertinggi.

Hal ini sesuai dengan pendapat Slameto, (1995:35), bahwa kegiatan belajar mengajar dipengaruhi oleh beberapa faktor, diantaranya adalah media pembelajaran dan model pembelajaran, pemilihan media yang tepat, dapat membantu siswa untuk membentuk pengertian di dalam jiwanya sehingga siswa dapat mengaplikasikannya dalam kehidupan sehari-hari.

Penggunaan media komik, dapat membatu peserta didik untuk minat membaca. Media komik disajikan dengan cerita dan tampilan menarik sehingga peserta didik tertarik dan senang dalam membaca dan mempelajarinya. Mempermudah peserta didik untuk belajar dan mengembangkan imajinasinya ke dalam bentuk tulisan, dan menambah kosa kata dalam menuangkan ide ke dalam tulisan.

Dengan proses pembelajaran yang telah dilakukan pada uji coba terbatas dan uji coba luas menunjukkan bahwa, dengan menggunakan media komik membantu siswa dalam meningkatkan kemampuan siswa dalam hal menulis. Di samping itu proses pembelajaran yang dilakukan dengan menerapkan media komik yang dikembangkkan menjadi lebih bermakna dan menyenangkan.

Kegiatan pembelajaran dengan menggunakan model pembelajaran round table sangat cocok diterapkan pada anak kelas IV SD karena siswa dapat menyumbangkan idenya secara bergiliran / memberikan sumbang asih dalam menulis cerita. Saat siswa menggunakan model round table mereka merasakan hal yang menarik dan tidak monoton sehingga kegiatan menulis terasa menyenangkan. Model pembelajaran round table dapat mengatasi masalah yang dialami peserta didik. Peserta didik diberikan kesempatan untuk berinteraksi secara aktif dalam kelompok belajarnya, karena tujuan kelompok adalah menghasilkan suatu penyelesaian tugas dan melaporkannya dalam diskusi kelas.

Model pembelajaraan kooperatif tipe round table adalah pembelajaran kooperatif struktur sederhana yang mencakup banyak konten, dapat membangun kerjasama dan semangat dalam kelompok, serta melatih siswa dalam menggabungkan tulisan. Berkaitan dengan hal ini Huda (2011:141) menyatakan "dalam kegiatan Round table atau keliling kelompok, masing-masing anggota kelompok berkesempatan untuk memberikan kontribusi mereka dan mendengarkan pandangan anggota yang lain"Dengan teknik ini seorang guru dapat membantu siswa untuk membuka diri terhadap proses belajar yang menyenangkan dan menjauhkan dari kondisi pembelajaran yang tegang di kelas. Siswa lebih tertarik untuk menuangkan ide atau gagasan dalam bentuk tulisan dan dapat mengurangi rasa kejenuhan siswa dalam pembelajaran menulis.

Diskusi hasil tahap pengembagan berdasarkan hasil ujicoba I dan ujicoba II. Setelah draf II media komik disetujui oleh tim validator, selanjutnya buku ajar tersebut diujicobakan kepada dua puluh lima siswa kelas IVA secara terbatas. Hasil ujicoba I kemudian direvisi hingga menjadi draf III. Draf III selanjutnya diujicobakan kembali, kegiatan ujicoba draf III adalah ujicoba II.

Ujicoba draf III terdiri atas pengamatan terhadap aktivitas siswa dan guru menggunakan draf III buku ajar, evaluasi hasil belajar siswa, serta respon siswa dan guru terhadap penggunaan buku ajar draf III. Aktivitas guru dan siswa diamati oleh dua orang pengamat. Masing - masing hasil pegamatan memperoleh skor $98,4 \%$ untuk aktivitas guru dan $97,1 \%$ untuk aktivitas siswa. Kedua hasil ini menunjukan bahwa aktivitas guru dan siswa saat menggunakan draf III media komik selama pembelajaran dapat disimpulkan baik sekali. Adapun untuk hasil belajar siswa saat ujicoba II yaitu $\geq 67$ dengan rata -rata keseluruhan siswa kelas IV memperoleh 85 .

Secara keseluruhan draf II sudah baik digunakan tetapi masih dibutuhkan sedikit revisi untuk menyempurnakan penggunaannya pada siswa sehingga hasilknya lebih optimal lagi tujuan pembelajarn yang telah ditentukan.

Trianto (2007:74) menyatakan bahwa media komik adalah media belajar yang baik dalam proses pembelajaran di kelas maupun belajar mandiri yang memuat materi pembelajaran, kegiatan pembelajaran berdasarkan konsep materi, informasi, contoh penerapan materi dalam kehidupan seharihari latihan diri atau kelompok dan masalah dalam khidupan sehari-hari yang perlu didiskusikan sehingga buku ajar dapat membuat siswa dapat 
belajar secara optimal dan mendapat nilai hyang melampaui rata-rata hasil KKM.

Tes hasil belajar siswa bertujuan untuk mengetahui keefektifan media komik yang dikembangkan dan mengukur hasil belajar siswa. Tes hasil belajar yang diberikan pada siswa kelas IV SDN Simokerto VI/140 Surabaya dilaksanakan pada akhir pertemuan pembelajaran .Tes yang diberikan berupa latihan menulis cerita yang terdapat dalam draf III media komik. Hal ini sesuai dengan perolehan skor hasil belajar siswa yaitu $\geq 67$. Ratarata keseluruhan siswa kelas kelas IV memperoleh 85.

Dalam Kamus Besar Bahasa Indonesia (2008:1170), respon adalah tanggapan atau reaksi. Dikaitkan dengan hal sebelumnya, respon diartikan sebagai tanggapan atau reaksi siswa terhadap kegiatan pembelajaran dengan menggunnakan buku ajar berbasis teori kecerdasan majemuk. Respon siswa terhadap penggunaan draf III media komik selama pembelajaran sangat baik. Hal ini terlihat dari hasil respon siswa saat menjawab pertanyaan. Hasil rekapitulasi perolehan respon siswa menunjukan perolehan rata-rata keseluruhan yaitu $97,2 \%$ dari hasil tersebut termasuk dalam interval $80 \%-100 \%$ yang dikatagorikan baik sekali.

\section{SIMPULAN}

Simpulan yang dipaparkan ini berdasarkan hasil penelitian yang disesuaikan dengan rumusan masalah, maka dapat diambil simpulan bahwa dalam proses pengembangan produk melalui tiga tahapan yaitu tahap pendefinisian, perancangan, dan pengembangan. Tahap pendefinisian meliputi lima langkah pokok yang harus dilakukan, yaitu analisis awal akhir, analisis siswa, analisis konsep, analisis tugas, dan analisis tujuan pembelajaran. Tahap perancangan meliputi penulisan dan penyusunan buku suplemen dan validasi draf I. Tahap pengembangan meliputi revisi hasil validasi draf I, validasi buku suplemen draf II, revisi hasil validasi draf II, menjadi draf III, uji coba terbatas dan uji coba luas.

Proses pengembangan media komik dalam pembelajaran model round table untuk meningkatkan kemampuan menulis siswa kelas IV SD terlaksana sesuai dengan tiga tahapan yang terdapat dalam model pengembangan 4-D yang meliputi tahap define (pendefisian), tahap design (perancangan), dan tahap develop (pengembangan).

Dilihat dari produknya, penilaian berdasarkan pada validasi draf II, perolehan skor validasi menunjukan media komik dikembangkan merupakan media yang sangat baik untuk digunakan dengan persentase kelayakan 94,5\%. Dilihat dari penggunaannya, penilaian media komik ini berdasarkan pada aktivitas guru dan siswa saat menggunakan media komik, hasil belajar siswa, serta respon guru dan siswa. Penilaian berdasarkan pada hasil pengamatan yang dilakukan. Aktivitas guru dan siswa masing- masing memperoleh skor $98,4 \%$ dan $97,1 \%$. Hasil belajar siswa memperoleh rata-rata 79,9. Respon guru dan siswa masingmasing memperoleh $96,9 \%$ dan $97,2 \%$.

\section{DAFTAR PUSTAKA}

Hamalik, Oemar. 2010. Psikologi Belajar \& Mengajar. Bandung: Sinar Baru Algesindo.

Huda, M. 2011. Cooperative Learning Metode, Teknik, Struktur dan Model Penerapan. Yogyakarta: Pustaka Pelajar.

Lie, Anita. 2010. Cooperative Learning. Jakata: PT Grasindo.

Mccafferty, Stevn G, dkk. 2006 . Cooperative Learning and Second Languange Teaching. New York: Icambridge University Press.

Slameto. 1995. Belajar dan faktor-faktor yang Mempengaruhinnya. Jakarta: Rineka Cipta.

Sugiyono, 2008. Metode Penelitian Pendidikan Pendekatan Kuantitatif, Kualitatif, dan $R \& D$. Bandung: Alfabeta

Tarigan, H. G.2008. Menulis Sebagai Suatu Keterampilan Berbahasa. Bandung : Angkasa.

Trianto, 2007. Model Pembelajaran Terpadu dalam Teori dan Praktek. Jakarta: Prestasi Pustaka Publisher. 